\title{
Mare nostrum: the political ethics of migration in the Mediterranean
}

\author{
Rainer Bauböck
}

\section{Correspondence:}

rainer.baubock@eui.eu

European University Institute,

Fiesole, Italy

\begin{abstract}
In the political theory debate about open borders and the ethics of immigration control there has been little discussion of trade-offs and a lack of distinctions between admission claims. This paper argues that freedom of movement, global distributive justice and democratic self-government form a trilemma that makes pursuing all three goals through migration policies difficult. It argues also that there are distinct normative grounds for refugee protection, admission of economic migrants and reciprocity-based free movement. Refugees have claims to protection of their fundamental human rights. Economic migrants should be admitted if there is a triple benefit for the receiving country, the country of origin and for themselves. Free movement is based on agreements between states to promote international mobility for their own citizens. These three normative claims call for different policy responses. However, in the current migration across the Mediterranean flows and motives are often mixed and policies of closure by destination states are bound to contribute to such mixing. The paper concludes by suggesting that the European Union as a whole has special responsibilities towards its geographic neighbours that include duties to admit asylum seekers, displaced persons and economic migrants.
\end{abstract}

Keywords: Migration ethics, Mediterranean migration, EU migration policy, Refugees, Free movement, Economic migrants

\section{Introduction}

The so-called 'refugee crisis' has turned into a crisis of the European Union. 1.3 million refugees and migrants arriving in 2015 was a big number compared to previous years, but a small one compared to the much larger refugee populations hosted by Jordan, Lebanon and Turkey. The failure of EU governments to replace the Dublin Regulation and agree on a fair distribution of responsibilities casts now a dark shadow over the future of the Union itself. The main reason for this development is the rise of populist anti-immigrant sentiments and parties that are now in power in more European capitals than ever and many of whose ideas and discourses have been adopted by mainstream parties in attempts to regain lost voters.

This is a remarkable shift. When the Italian government started the Mare Nostrum rescue operation in October 2013, it did so because the images of overcrowded boats and the reports about the numbers of drowning migrants in the Mediterranean had led to a public outcry and demands for a humanitarian response. In 2015 it was the images of refugees huddled together in Budapest's Keleti train station and those of lines of refugees

(c) The Author(s). 2019 Open Access This article is distributed under the terms of the Creative Commons Attribution 4.0 International License (http://creativecommons.org/licenses/by/4.0/), which permits unrestricted use, distribution, and reproduction in any medium, provided you give appropriate credit to the original author(s) and the source, provide a link to the Creative Commons license, and indicate if changes were made. 
marching towards the Austrian border that triggered an outpouring of voluntary assistance dubbed "Willkommenskultur" (culture of welcome) and Chancellor Merkel's decision to temporarily suspend the Dublin Regulation and keep Germany's borders open.

Today, the same images are still used, and they serve to support a Hungarian law criminalizing NGOs for providing support to asylum seekers and an Italian policy of turning away NGO ships that have rescued migrants at sea. The main political conflict between EU governments is no longer about how open borders should be for refugees but about whether closure of external borders must be coordinated at EU level or can be more effectively brought about by unilateral actions of member states forcing others to close their borders too, including internal ones within the Schengen area. Moreover, those who call for a full closure of the Mediterranean Sea and Balkan land routes claim today the moral high ground for themselves. They argue that no-entry policies for asylum seekers in Europe and massive deportations of those already present in the EU territory are necessary in order to save lives, since these policies are the only way to break the traffickers' business model by deterring their clients from the perilous journey across the Mediterranean.

This argument can be easily debunked philosophically as exhibiting the typical flaws of a moral utilitarianism that is ready to sacrifice fundamental rights of individuals for the sake of a presumptive but uncertain greater benefit of greater numbers. It is also easy to smell and denounce its political hypocrisy when the transparent goal is not to prevent migrants from drowning but to win votes through whipping up xenophobia and to dismantle European integration through flagrant non-compliance with the EU's laws and values. But it is not so easy to flesh out an alternative vision for a political ethics of migration in Europe.

I will take a step back from the current debates and ask more fundamental questions about what duties democratic states have to admit migrants and refugees. Political philosophers have been discussing since the 1980s controversy between Carens (1987) and Walzer (1983) whether immigration controls can ever be legitimate. I will not rehearse this broad debate here. Instead, my goal is to think through the political ethics of migration as they present themselves in today's world and in particular in its small European corner. This world is neither one of open borders, nor is it one in which democratic states have full discretionary powers to control immigration. It is a world in which claims of territorial admission differ fundamentally for refugees, economic migrants, family members of immigrants, mobile EU citizens and international tourists.

Before trying to sort out these claims, we should consider first what we expect from a political ethics of migration. Should it deliver a vision of a globally just society or guide political decisions here and now ${ }^{1}$ Think about what you would expect from medical ethics. A medical ethics board would fail at its task if it tells doctors that the disease they have to cure will no longer exist in a distant future or if it tells them that attempting to cure patients is useless since they are going to die anyhow at some point. This does not diminish the task of medical science to eradicate diseases and further increase human life expectancy, nor that of ethical theorists to think about health policy dilemmas that might arise with further medical progress. We just need to keep these tasks fairly separate.

In the field of normative theories of migration, we find a large literature on open border utopias, whose best defender is Joseph Carens. ${ }^{2}$ Critical theories, on the other 
hand, have tended to produce migration dystopias, such as Giorgio Agamben's writings (Agamben, 1998), which have been used to describe the situation of refugees and irregular migrants as a permanent state of exception under which they are reduced to their bare lives. Such utopias and dystopias are not useless since they may help to sharpen our moral sensibilities and rally us politically behind morally worthy goals. But they do not provide much guidance for migration policy decisions here and now.

At the same time, you also would not expect a medical ethics board to provide a surgeon with an instruction manual on how to cut out an inflamed appendix. Unlike medical practice itself, medical ethics must start with goals and principles, apply these to specific categories of patients and spell out practical guidelines of dos and don'ts. Similarly, a political ethics of migration must discuss how migration ought to be regulated so that certain goals are achieved as best as possible, or that the principles behind the policies can be accepted as just and legitimate.

A political ethics of migration must start with goals and principles but cannot end there. It must also respond to circumstances. The medical ethics of fighting Ebola in Africa will differ from that of treating Alzheimer patients in Europe. The context of migration in the Mediterranean is similarly different from that in other parts of the world. Taking contexts into account is difficult for political theorists who are trained to think non-contextually. The point of doing so is obviously not to become parochial and ignore the rest of the world. It is instead to compare across contexts and to look for both similarities and differences.

For example, Canada and Australia are often mentioned as models from which Europe should learn. There are relevant similarities: we are comparing here liberal democracies with long traditions of immigration. But there are also important differences: in Europe we have, first, regimes of international free movement and open borders within the EU combined with joint external border controls. Secondly, there are huge disparities of wealth, security and democracy with Europe's immediate vicinity, and especially between the Northern and Southern shores of the Mediterranean.

\section{Conflicting goals: the free movement trilemma}

But why should we not start from a long-term goal of open borders? In an essay published ten years ago, I argued that there is a tension between three basic values invoked by political theorists debating this question (Bauböck, 2009). Some promote open borders as a response to global distributive injustice. Nobody deserves to be born in a poor or rich country and those who are worse off thus have a moral claim to improve their opportunities by moving to a wealthier society. Others argue for open borders on the basis of individual freedom. Just as people enjoy freedom of speech and association unless they slander others or subvert the public order, so they should be able to move across borders unless their migration causes serious harms. Carens (2013) defends both the global justice and the individual freedom argument. But notice how these arguments apply to contrasting contexts. The former requires states to open borders in response to pervasive injustice in the present world whereas the case for freedom seems stronger in a globally more equal world, in which free movement no longer drains poor countries of human capital or undermines redistributive welfare regimes in wealthier destination countries. A third group of theorists, the most prominent among whom are Miller (2016) and Walzer (1983), consider immigration control instead as a matter of 
democratic self-determination by receiving countries that have a right to own their territory and shape the composition of their own citizenries.

I want to take this argument now a step further by suggesting that the conflicts between these three goals of social justice, individual freedom and democratic self-government can be described as a trilemma: a political ethics of migration can combine two out of the three goals but cannot address all three simultaneously. ${ }^{3}$

The democratic legitimacy of governments depends on defending legitimate interests of their citizens and residents. Foremost among these interests are those in domestic social justice. In the current world with its increasing opportunities for geographic mobility and huge inequalities across borders, opening borders for free movement would jeopardize the capacity of governments to protect and promote domestic social justice. If we are willing to sacrifice democratic self-government of independent states, then opening borders might achieve a massive global redistribution of wealth and opportunities while at the same time enhancing greatly individual freedom. This response is defended by libertarians who want to demolish welfare states as well as by global democrats aspiring for a world state that would turn all migration into internal free movement.

A second possibility is to combine the goals of global justice and national democracy if one is ready to sacrifice free movement. Massive resource transfers towards the global South and support for democratic development there provide in this view alternatives to migration from the South to the North. The problem with this approach is not only that it sacrifices an important liberty, but also that it tends to ignore that the onset of development triggers stronger outmigration and that migration can play a positive role in reducing global inequalities.

The third combination seems perhaps the most unlikely one. The goals of democratic self-government and individual freedom of migration can be pursued simultaneously if we regard free movement as a citizenship right instead of a human right. ${ }^{4}$ This would mean that democratic states commit to promoting international mobility opportunities of their own citizens through concluding free movement arrangements with other states. In this view, free movement presupposes certain levels of democratic stability and economic development.

This response seems hard to defend if it means that global justice is sacrificed for the sake of expanding mobility opportunities of the better-off citizens of the global North. However, such an approach does not rule out pursuing a separate agenda of promoting global justice through either resource transfers or controlled migration that is conducive to economic and democratic development. Indeed, as I will argue, controlled migration as well as regionally limited free movement regimes can contribute importantly to the goals of global social justice. What we need to reject in order to escape from the trilemma are the ideas that global free movement is the right response to global inequality or that global equality can be better achieved with closed borders.

I suggest that this is the best way out of the trilemma. It requires that we distinguish quite sharply between free movement and admission claims that presuppose legitimate immigration control.

\section{Three questions about immigration control}

Let me now flesh out this distinction. In the absence of immigration control, international migration would turn into geographic mobility of the same kind as internal 
migration within a state territory. Immigration control is thus constitutive of the very phenomenon that we describe and count as international migration. Yet not all potential immigrants have the same claims to be admitted. We can distinguish three broad categories by asking a series of three questions about immigration control.

The first question is whether a state exempts a whole category of migrants from immigration control. By doing so it creates two categories that we may call free movers, for whom international migration is not essentially different from internal mobility, and controlled migrants. Free movement for EU citizens provides the obvious illustration for the former, but similar arrangements exist between Australia and New Zealand and among ECOWAS and MERCOSUR member states. As we will see shortly, however, this category is much broader and has great potential for further expansion.

The second question is whether a state distinguishes further within the category of controlled migrants between those who have individual admission claims and others who don't. Let's call the former entitlement migrants. They include two main types: refugees with a right to asylum and those whom I suggest to call "pre-connected migrants" whose admission claims rely on their special ties to the destination country.

The third and final question distinguishes further within the category of non-entitled migrants by asking whether states have duties to take in certain numbers of immigrants who do not have individual admission claims. I will argue that liberal states should adopt such policies towards displaced persons as well as towards economic migrants.

This leaves a broad residual category of potential migrants towards whom states do not have any positive admission duties. From a liberal perspective this does not entail that states can turn away such would-be immigrants in the same way as the owner of a house may turn away a stranger by simply not answering the doorbell. Liberal democracies derive their legitimacy not only from representing the will of their people, but also from governing according to the rule of law. As pointed out by Schotel (2011), the coercion that states exercise over would-be immigrants through their immigration control qualifies as legally binding for those who are turned away only if these persons have some legal standing. This means that liberal states have to answer when the doorbell rings and provide reasons if they keep the door shut.

\section{Conditions for free movement: the parable of the double doors}

The three questions provide only a first rough categorization of migrants by the kind of control that states may legitimately exercise over them. In order to dig deeper, we need to consider next what migrants may have to say when asking for admission.

Let me illustrate the ethical guidelines that I want to defend with a Kafkaesque parable. Imagine a large palace in which most rooms are connected to several other adjacent rooms by double doors. There are people living permanently in these rooms and each room has a guard who is in charge of the doors. Let's assume that the rooms are governed democratically. The guards then represent the people living in their respective rooms; they have to protect their individual rights and follow their collective instructions.

Suppose now that you live in one of these rooms and want to enter another one. You approach the guard in your room and ask him to open one of the doors for you, which he is obliged to do. But since these are double doors, you find yourself in front of another door that is still closed. You knock and ask the guard in the other room through the closed door to let you in. You have not elected that guard and there are other doors on 
which you could have knocked, so he is not obliged to open the door, but he must listen and respond to your request. He asks you to explain why you want to enter his room rather than any of the others. Here is a list of possible reasons that you might give:

If you say: "Don't you recognize me? I am returning home from a long stay in another part of the palace", the guard will have to open the door widely for you. If you say: "I want to see a famous painting in your room", he may let you in, but only for a short visit and for an admission fee. If you say: "A year ago you admitted my spouse to live in your room", he ought to let you settle in his room. If you say: "I cannot find any work to earn a living in my room, but I am really good at interior decoration and your room needs a makeover", the guard ought to consider your request favourably, since your situation would improve while you would also provide a service to those who live in his room. And if you say: "The guard whom we elected in my room has turned out to be a killer and has threatened to go after me", he ought to open the door immediately and provide you with protection before examining whether your story is true.

Let's modify the scenario now and imagine that the guards are employed by the general palace management and together with all the other people living in the palace you have elected the managing board. In this case you will certainly elect a board that promises to keep all the connecting doors open. The management has then the power to instruct the guards to let people walk around freely inside the palace and can sack any of them who starts to block a door or demands a bribe for opening it.

Our initial scenario represents a world of independent states, the second one a world state or internal migration within states. In the first scenario, we get rights of return and family reunification for pre-connected migrants who have strong ties to a destination country already before moving there, conditional admission of economic migrants, and an individual right to asylum. In the second scenario these distinctions no longer matter because everyone enjoys freedom of movement.

Joseph Carens' 'cantilever argument' (Carens, 2013, pp. 237-245) suggests that the same individual interests which protect free movement within states as a human right ${ }^{5}$ apply to free movement across international borders. Yet this blurs the clear distinction between the two scenarios. It is simply not enough to point to the similarity of individual interests in internal and international free movement. We also need to consider the institutional background conditions under which such a right can be realized. According to Blake (2013), these conditions include a unified jurisdiction, which is present in the second but absent in the first scenario. Of course, some may argue that a world state is a desirable utopia that states should strive to realize in order to enable global free movement, amongst other worthy goals. No matter whether one agrees or regards a world state instead with Kant as a dystopia that is likely to lead to either despotism or anarchy, one cannot derive a political ethics of international migration for the current world from the second scenario.

We can, however, modify the first scenario in a less radical way. If the people living in a subset of adjacent rooms can communicate with each other, visit each other and even collaborate in joint projects, they might ask their guards to keep the doors open between these particular rooms. In this case, they will want their guards to agree also on a set of common rules for admission of people from the other rooms of the palace that are not included in the agreement. Free movement can thus be expanded in a world of independent states on a basis of reciprocal agreements between these. Since 
distances have shrunk due to global communication networks and mobility, it should also be possible to conclude free movement agreements between non-adjacent states, for example between the EU, Canada, Australia and New Zealand.

Moreover, free movement rights proliferate at the individual level even in the absence of such agreements if states tolerate multiple citizenship. Emigrants' countries of origin as well as democratic countries of immigration increasingly tolerate dual citizenship both for first generation migrants who choose to naturalize and for second generations born to foreign parents. This global trend in state practice is supported by a normative principle that citizenship ought to reflect ties of membership between individuals and particular polities (Bauböck, 2017). International migrants have by default relevant membership ties to at least two states. States exposed to emigration and immigration should therefore generally tolerate dual citizenship, which entails an unconditional right to return to two states and thus an entitlement to free movement between them.

In this latter manifestation free movement is not a privilege of citizens of wealthy democracies, but traces instead major migration flows, which frequently connect the global South and North. This still does not take us towards a just global distribution of mobility rights. As shown by Harpaz (2018), demand and opportunities for obtaining a second citizenship in the EU are strongest among the wealthy and educated elites of states with "second tier citizenships" in Eastern Europe and Latin America.

\section{Pre-connected migrants and free movers}

Let me now consider in more detail and in the same order the reasons that would-be immigrants can provide, starting with pre-connected migrants - a category that to some extent cuts across the others.

There is one group of immigrants that all states have to let in without further conditions. These are their own citizens. They are not usually called immigrants, but they do cross an international border, and many have spent years or even all of their lives abroad and may intend to settle for good in the country. Their right to do so is enshrined in international human rights declarations and conventions - e.g. in Art. 13 (1) of the Universal Declaration of Human rights: "Everyone has the right to ... return to his country". 6 The UN Human Rights Committee has clarified that the possessive pronoun in "his country" does not only refer to citizens but also to long-term resident foreigners who have a claim to return to places where they have built their lives. ${ }^{7}$ They are quasi-citizens even if they have not been granted or have not chosen naturalization. Their claims to return are for this reason similar to those of citizens. The right of the latter to return is furthermore protected by the human right not to be arbitrarily deprived of one's citizenship (UDHR Art. 15 (2)). Today, most liberal states do not consider either long-term residence abroad or voluntary acquisition of another citizenship as a sufficient reason for stripping their nationals of their legal status and right to return.

Claims to family reunification have been derived from the right to private and family life enshrined in Art. 8 of the European Convention on Human Rights. Incoming family members and their relatives already settled in the country have the same human right to family life, but this is not sufficient to trigger a territorial admission claim. A membership-based right of the settled person (based on her citizenship or long-term residence) is needed to support the immigration claim. In the absence of a general 
human right to free movement, there is also no human right to immigrate for the sake of finding a spouse. For the same reason, immigrants can be told to reunite with their families back home after returning there if they do not have an independent membership-based right to stay. While returning citizens enjoy both a human and a citizenship-based right to admission, these rights are split between different persons in family reunification.

One may wonder why, in contrast to a rather weak right to family reunification, the right to return to one's country is one of the few human rights that are not further qualified $^{8}$ and seems thus nearly as absolute as the right not to be tortured. The reason is not that returning citizens have stronger needs than families separated by migration, refugees or those who desperately want to improve their economic opportunities. It is instead that states are responsible for their own citizens vis-à-vis other states. Citizenship is a global sorting mechanism (Brubaker, 1989) that assigns responsibilities for individuals' protection to states. States that fail to readmit their own citizens and to offer them diplomatic protection while they are abroad become in a way 'externally failed states' that do not perform one of the core functions of independent states in their relations to other states.

As I have already explained above, in a world of independent states, free movement can be solidly built on the bedrock of citizens' right to return. No matter whether free movement is based on dual citizenship, regional integration regimes or reciprocal agreements between distant countries, it is always granted to those who bear particular passports and is thus not a universal human right. Authors who support an ideal of global free movement, as I do, may find a strategy of expanding citizenship-based mobility rights disappointing, because it does not address the injustice of the global birthright lottery (Shachar, 2009) and promises only a slow path towards the ideal, with the speed of travel depending on progress of economic and democratic development in the global South. This raises the question of what ethical principles should guide the admission of unconnected migrants who are not yet citizens within a free movement regime.

\section{Economic migrants}

Economic migration ought to be guided by a goal of pareto-optimal triple wins. If economic migration is beneficial for the host state, the individual migrant and the country of origin, then economic migrants ought to be admitted. This proposition needs to be qualified in several ways.

First, it is not obvious why admitting self-interested migrants for self-interested reasons should be a state duty rather than something that states are at liberty to do or not. ${ }^{9}$ The answer to this objection is that we still need to place economic migration within the larger ethical framework under which wealthy democracies have global justice duties towards poorer migrant sending countries and justification duties towards would-be migrants whom they reject. These two normative requirements are sufficient to support an ethical duty to set up mutually beneficial economic migration programmes.

Second, as I have suggested above, destination countries ought to have an economic immigration programme under which certain numbers of migrants can apply for admission. Individual migrants do not necessarily have a personal claim to admission. The reason is that the collective benefits for the receiving and sending country will 
naturally depend on the numbers and qualifications of people seeking work in the former and diminishing the workforce of the latter.

Third, the triple win rationale applies to first admissions, but not to subsequent decisions about permanent residence or access to citizenship. Having lived and worked in a host state for some years, economic migrants strike roots and acquire individual claims to stay. Moreover, as argued by Walzer (1983, pp. 53-63) democracies cannot legitimately rule over those whom they keep in a position of permanent foreigners.

Fourth, states are primarily responsible for the opportunities and welfare of their own citizens and residents. ${ }^{10}$ Furthermore, economic immigration programmes are asymmetrically dominated by destination states, not only because these tend to be more powerful, but also because they must be able to select those whom they are ready to admit to their territory and labour markets. These normative and realist reasons make it more difficult to prevent that migrants are losing out by being exploited and that countries of origin are damaged through brain drain. The triple win criterion suggests thus that economic migration programmes should not be exclusively run by destination states. They require an additional layer of global migration governance, i.e. a set of international legal norms, ${ }^{11}$ mediation and supervision by international organisations, and governance bodies in which migrants and sending states are represented next to receiving states.

Fifth, the condition that economic migration should also be beneficial for sending countries does not entail that these have a right to suspend their citizens' freedom of exit in order to prevent an outflow of 'human capital. ${ }^{12}$ The goal must instead be to design economic migration programmes in such a way that the return flow of remittances and qualifications contributes to the economic development of the sending country.

This is a very incomplete list of ethical guidelines for economic migration policies, but it has quite radical implications for Europe. It seems clear that there is a large potential for economically and demographically beneficial immigration from Africa to Europe that could generate a triple win if it were well designed. The current reality is, however, that family reunification and refugee admission are pretty much the only available legal channels for immigration into the EU from Africa, while there is substantial regular economic immigration from other parts of the world that gets little attention. ${ }^{13}$ The result of Europe's lack of responsiveness to economic immigration from its Southern neighbourhood is a triple loss. Economic migrants are pushed into the arms of human traffickers, destination countries receive irregular migrants who clog their asylum system and remain blocked from regular labour markets. And countries of origin do not reap many of the benefits in remittances and transnational links to Europe that regular economic migration could yield for them.

\section{Refugees and displaced persons ${ }^{14}$}

The ethics of refugee admission is very different from that applying to economic migrants. In order to understand what the claims of refugees are, we do not need to stick to the narrow definition provided by the Geneva Refugee Convention that can only be understood in its historical context. The UNHCR's mandate has anyway been extended far beyond this definition (Aleinikoff \& Zamore, 2018). Among political theorists there is a broad consensus that international refugees are persons whose states of citizenship fail to protect their fundamental human rights and for whom asylum granted by other 
states is the only way of restoring protection in the short run (Carens, 2013; Gibney, 2015; Owen, 2016).

The more controversial question is what duties states have towards refugees. As with migration in general, it is useful to start with special duties in order to avoid the misleading idea frequently exploited by populists that each state is expected to be open for all the world's refugees. Just like other migrants, refugees are often "pre-connected" to potential host states and such pre-connections create special responsibilities. If states have contributed to a refugee crisis through supporting an authoritarian regime or selling arms to militias fighting a civil war, they have a remedial responsibility to take in refugees fleeing from such countries. The US did take in a significant share of Indochinese boat people after the end of the Vietnam war, but failed to do so for refugees from Iraq.

The second type of special duty emerges from social connections to potential destination states that refugees have already before departure. Just like other migrants, refugees have claims to family reunification with previously admitted refugees or economic migrants. Since long-term refugees need to build entirely new lives in a host country, this argument extends to broader social and cultural connections that facilitate their integration, such as sharing a language with a particular host society or the presence of an already settled co-ethnic immigrant community there.

The third special duty is positional. Countries that are in a better position to protect refugees have special duties to do so compared to far away ones. Positional duties will generally fall on nearby states and will be proportionate to their capacity to provide protection. Malta may be closer to the North African coast than Italy, but it has fewer capacities.

Current European asylum policies rely heavily on an ethics of positional duties for first countries of asylum with some nods towards special connection duties. There are two obvious problems with this approach. First, it lowers the overall capacity of the international community to provide protection to the level of aggregate capacities of those states that carry special responsibilities for refugees. Second, the distribution of burdens among states is unfair if countries that are closer to a refugee emergency and that have already taken in more refugees from a particular origin in the past are obliged to take in even more.

This unfairness arises as an ethical problem only if we do not think of refugee protection as a purely humanitarian duty. A good swimmer who sees a child drowning near a beach has a moral duty to rescue the child. It would be odd if she refused to rescue a second child or asked others to compensate her for the effort. However, if many people have drowned at this beach, the municipality ought to put lifeguards there who are paid from tax revenues collected from the town's residents.

But why should states that are far away and have not contributed through their own policies to a refugee emergency share responsibilities and burdens with other states? As political theorist Owen (2016) has argued, the legitimacy of states' coercive power depends on their capacity to protect fundamental human rights in their territory. If some states fail to do so, all the others acquire a responsibility to provide surrogate protection. Refugee protection is thus, in Owen's word, not just a humanitarian duty; it is a 'legitimacy repair mechanism' in the international state system.

This argument provides support for general duties of states to contribute to international refugee protection. Yet it leaves open two big questions. What can 
motivate self-interested states to comply with these duties? And what is it that they have to contribute?

The first question conjures up a prisoners' dilemma (Noll, 2003). States are better off collectively if each contributes a fair share, but they are better off individually if they can pass on the buck to others. Prisoners' dilemmas can often be solved if the same players have to play with each other repeatedly and if they also have to play different kinds of games. Non-cooperative players that dominate one game can then be sanctioned in another one. If they are aware of this, they may play cooperatively from the start. Prisoners' dilemmas can even be avoided altogether if players agree ex ante on coordinating their actions.

The international society of states provides only weak resources for resolving the refugee protection dilemma, but the European Union offers the best possible conditions for doing so. It has institutionalized the necessary coordination mechanisms and its member states play iterated and multiple games in which the potential for punishing, and the incentives for avoiding, non-cooperative behaviour are strong. The EU has thus the institutional capacity for ensuring compliance. Moreover, in the EU context with its internally open borders and joint control of external borders, asylum seekers enter EU territory rather than merely the national territory of a particular member state. Positional responsibilities for refugee emergencies in Europe's neighbourhood apply therefore to the EU as a whole. It follows from these two premises that the EU has special duties to establish a system of fair responsibility sharing among its member states even if no similar system can be established at the global level.

This does not mean that refugees ought to be distributed across EU member states according to a formula measuring integration capacities, such as the one used by the EU Commission's 2015 relocation scheme. Sending refugees to countries where they don't want to go and that don't want to have them is not just bad policy; it is also ethically wrong if the primary goal is to provide effective protection, which includes prospects of integration, to the largest number of refugees. Standards of fairness must apply to member states' contributions to overall refugee protection, not to the numbers of refugees each of them takes in. If a state wants to accept fewer refugees than initially allocated to it in a fair scheme, it ought to pay or transfer other resources to those states that take in more. If these transfers reflect the costs that a preference for keeping out refugees imposes on the refugee admitting states, this should avoid perverse incentives for states that want to be seen as being hostile to refugees in order to shirk their responsibilities. Tradeable refugee quotas combined with a matching mechanism that takes into account non-discriminatory preferences of states for certain refugees and preferences of refugees for certain destinations could provide fair solutions (Rapoport \& Moraga, 2014).

This account of duties towards refugees is still incomplete. In the words of Aleinikoff and Zamore (2018), it has an 'exilic bias' that considers only long-term settlement and access to a surrogate citizenship in European states as a solution. For millions of coercively displaced persons, this solution is not adequate. Most lack the financial means and physical fitness required to reach European shores, and many want to stay close to home and return there if and when possible. Betts and Collier (2017) have suggested that admitting asylum seekers to European states is wrong because it lures many people into the Mediterranean death trap and diverts attention from the more urgent task of 
providing protection, jobs and education to millions stranded in refugee camps in the global South.

If the overarching goal is to provide effective protection to the largest numbers of refugees, then it would indeed be wrong to focus only on a fair distribution of responsibilities for asylum seekers among EU member states. We need to acknowledge instead that Europe as a whole has a special positional responsibility for its geographic neighbourhood and must mobilize resources for protecting and providing opportunities for displaced persons in Africa and the Middle East. Such efforts have to be closely synchronized with development policies. In this context, the question of who qualifies as a refugee fades into the background. As pointed out by Aleinikoff and Zamore (2018), the problem that needs to be addressed is massive displacement of people within and across international borders due to wars, failing states and economic or environmental collapse. These are also the 'root causes' that eventually push rather small numbers of refugees and migrants to seek asylum in Europe. Taking them in does not address the causes and does not help those who remain stuck in their region of origin.

Are non-entry policies and the aim to deter asylum seekers from trying to reach European borders and coasts then ethically justified after all? My answer is no for both principled and prudential reasons. The principled one is that refugees have individual rights to protection that have been enshrined in the Refugee Convention and the asylum laws of democratic states. The claims of refugees who have lost the protection of their citizenship of origin resonate with the principles on which democratic states ground their own internal legitimacy. The external function of citizenship as an assignment of responsibility for individuals to states similarly supports a robust individual right to asylum. The prudential reason is that, in the current European political climate, calls for protecting displaced persons outside Europe instead of accepting asylum seekers in Europe provide ammunition to those want to do neither. For populists whose agenda is to close off Europe towards the outside and to dismantle it from the inside, promises to provide assistance to refugees in Africa are just cheap talk that gives them a semblance of respectability.

Europe's response must combine a harmonized asylum system and fair sharing of responsibilities among EU member states with relief efforts for refugees in Africa and the Middle East. These efforts should enable displaced persons to stay close to their countries of origin, without being conditioned on preventing them from migrating elsewhere. On the contrary, sufficiently large resettlement programmes and channels for regular economic migration to Europe could be the most effective policies for destroying the traffickers' business model and saving migrants' lives. Since resettled refugees generally do not have individual claims to asylum at a particular destination, they would be treated almost like economic migrants from poor countries in terms of territorial admission policies, while the distinction between the two categories must be maintained for asylum seekers.

\section{Mare nostrum: an ethics of special responsibilities}

I have argued that pre-connected migrants, free movers, economic migrants and refugees have distinct claims that liberal democracies must respond to. Yet this multiple-channels-of-admission approach seems to create a new problem. Aren't these 
claims competing with each other? And if they are, whom should liberal states let in first or in larger numbers?

From a moral perspective the obvious answer seems to be: those who have the strongest needs. Should Europe then close its doors to economic migrants and its internal borders for mobile EU citizens until it has taken in a sufficient number of asylum seekers and resettled refugees? Something is clearly wrong with this answer. It emerges from two fallacies: the fallacy of measuring incommensurable claims using a single yardstick (of needs) and the fallacy of fixed admission capacities. If Europe stops internal free movement, its member states are likely to be less open for economic migrants and refugees both in terms of economic capacities and political attitudes. And looking around the world which wealthy democracies have taken in more refugees, these often turn out to be the same countries that have run extensive economic immigration programmes. Although it is certainly true at the local level that refugees, economic migrants and less skilled resident workers often compete for the same jobs, at the aggregate level the admission capacity of countries is not a fixed number but tends to expand with their general openness to migration and mobility.

For a political ethics of migration, it follows that states can be expected to honour the different admission claims in their own terms and may be entitled to limit numbers or impose conditions for each category (safe that of returning citizens) where their capacities are exhausted. What they must not do is adding up all immigrants in a single quota and closing their borders once that threshold has been reached.

The second problem that my account raises is how to handle mixed flows and mixed motives if admission claims need to be treated differently. When discussing the ethical principles that ought to guide admission policies I have distinguished refugees, economic migrants and free movers benefiting from interstate agreements. Empirically, these categories are, however, not neatly separate ones but overlap strongly. While I cannot imagine significant overlaps between refugees and free movers, there are very significant ones between refugees and economic migrants, on the one hand, and between the latter and free movers, on the other hand.

This problem goes beyond what a general political ethics of migration can deliver and requires political and administrative skills more than theoretical insights. Yet there is still a general lesson that can be drawn. Destination states themselves enhance the problem of mixed flows through indiscriminate policies of closure that push migrants with different motives and claims towards the remaining small doors of family reunification and asylum, which have not been designed for large flows, or towards the backdoor of irregular entry. If such a policy satisfies the normative criteria outlined in this article it would not reduce migration flows across the Mediterranean. It is also an illusion to believe that the right kind of development policies will reduce outmigration pressure in the short run. They are instead more likely to increase it by endowing more people with material and cognitive resources that enable their mobility before conditions improve opportunities to the point where people can afford to stay. Add to this the demographic discrepancy between the "youth bulge" in the MENA and African countries and the rapid ageing of European societies. The implication is that Europe faces a choice between accepting many more economic migrants from the South through regular channels and a policy of closure that violates EU values and undermines EU achievements such as open internal borders. 
The final lesson that I want to emphasize is that context matters for the ethics of migration - not only for explaining the different challenges that countries face because of their history or geographic location, but also normatively, in the sense of special responsibilities for neighbours. The Mediterranean was once the cradle of European civilization. Now it has become a graveyard for many who try to reach European shores. Europe shares a historic responsibility for economic and political crises in the neighbourhood that it colonized in the past. Today, Europe's future depends not only on keeping its internal borders open and defending democratic values against authoritarian governments that have sprung up in its midst, but also on how it responds to migration across the Mediterranean. In fact, these two challenges have become intertwined. 'Mare nostrum' was once an imperial claim. Today it has become an ethical imperative.

\section{Endnotes}

${ }^{1}$ See Frazer (2016).

${ }^{2}$ Carens (2013) distinguishes, however, between his ideal theory of open borders and a realist ethics of migration policy that starts from the assumption that states have a right to control territorial admissions.

${ }^{3}$ The structure of the trilemma is therefore similar to Dani Rodrik's famous globalization trilemma (Rodrik, 2011).

${ }^{4}$ See Oberman (2016) for a defence of free movement as a human right.

${ }^{5}$ This right is proclaimed by Art. 13 (1) of the Universal Declaration of Human Rights and Art. 12 (1) of the International Covenant of Civil and Political Rights.

${ }^{6} \mathrm{~A}$ slightly weaker formula is included in Art. 12 of the Covenant on Civil and Political Rights: "No one shall be arbitrarily deprived of the right to enter his own country."

${ }^{7}$ UN HRC, General Comment No. 27 on Freedom of Movement (Art. 12 CCPR), CCPR/C/21/Rev.1/Add.9, 1999, par. 20.

${ }^{8}$ In ICCPR Art. 12, freedom of internal movement and of leaving any country may be qualified only by restrictions "which are provided by law, are necessary to protect national security, public order (ordre public), public health or morals or the rights and freedoms of others, and are consistent with the other rights recognized in the present Covenant." The right not be deprived of the right to enter one's country is listed after these qualifications and must thus not be restricted by them.

${ }^{9}$ See Angeli (2018, p. 39) who argues that the consequentialist argument for mutually beneficial economic migration could even support paternalistic policies of forced migration.

${ }^{10} \mathrm{~A}$ strong global egalitarianism that denies the primary responsibility of states for the welfare of their own populations is hard to reconcile with democratic norms that legitimate governments have to be responsive and accountable to their own citizens.

${ }^{11}$ For recent efforts see the Global Compact for Safe, Orderly and Regular Migration that has been adopted by the UN in December 2018 as well as the more ambitious project for a Model International Mobility Convention.

${ }^{12}$ See Blake and Brock (2015).

${ }^{13}$ Poland, for example, has refused to admit relocated refugees but runs currently the largest programme for temporary migrant workers (mostly Ukrainian agricultural workers) in the EU.

${ }^{14}$ I have elaborated some of the ideas in this section in Bauböck (2018). 
Acknowledgements

A first version of this text was given as the keynote lecture at the IMISCOE annual conference in Barcelona on 2 July 2018. I have retained the style of a lecture rather than an academic article. I thank two anonymous reviewers as well as Max Haller for very helpful critiques and comments. These were too numerous to be individually acknowledged.

\section{Authors' contributions}

The author read and approved the final manuscript.

\section{Competing interests}

The author declares that he has no competing interests.

\section{Publisher's Note}

Springer Nature remains neutral with regard to jurisdictional claims in published maps and institutional affiliations.

Received: 28 August 2018 Accepted: 31 October 2018

Published online: 08 February 2019

\section{References}

Agamben, G. (1998). Homo Sacer. Sovereign power and bare life. Redwood City: Stanford University Press.

Aleinikoff, A. T., \& Zamore, L. (2018). The arc of protection. New York. Retrieved from https://cic.nyu.edu/news/arc-ofprotection-refugees-zamore.

Angeli, O. (2018). Migration und Demokratie. Ein Spannungsverhältnis. [Migration and Democracy. A Tension]. Ditzingen: Reclam.

Bauböck, R. (2009). Global justice, freedom of movement and democratic citizenship. European Journal of Sociology/Archives européennes de sociologie, 50, 1-31. https://doi.org/10.1017/S000397560900040X.

Bauböck, R. (2017). Democratic inclusion: a pluralistic theory of democratic inclusion. In R. Bauböck (Ed.), Democratic inclusion Rainer Bauböck in dialogue. Manchester: Manchester University Press.

Bauböck, R. (2018). Refugee protection and burden-sharing in the European Union. Journal of Common Market Studies, 56, 141-156. Betts, A., \& Collier, P. (2017). Refuge: Rethinking refugee policy in a changing world. London: Penguin Books.

Blake, M. (2013). Immigration, jurisdiction, and exclusion. Philosopy and Public Affairs, 41, 103-130.

Blake, M., \& Brock, G. (2015). Debating brain drain. May governments restrict emigration? Oxford: Oxford University Press. Brubaker, R. W. (1989). Introduction. In R. W. Brubaker (Ed.), Immigration and the politics of citizenship in Europe and north America, (pp. 3-27). Lanham and London: University Press of America.

Carens, J. H. (1987). Aliens and citizens: The case for open Borders. The Review of Politics, 49(2), 251-273.

Carens, J. H. (2013). The ethics of immigration. Oxford: Oxford University Press.

Frazer, M. (2016). Utopophobia as a vocation: The professional ethics of ideal and nonideal political theory. Social Philosophy and Policy, 33, 175-192.

Gibney, M. (2015). Refugees and justice between states. European Journal of Political Theory, 14(4), 448-463.

Harpaz, Y. (2018). Compensatory citizenship: Dual nationality as a strategy of global upward mobility. Journal of Ethnic and Migration Studies. https://doi.org/10.1080/1369183X.2018.1440486.

Miller, D. (2016). Strangers in our midst. The political philosophy of immigration. Cambridge: Harvard University Press.

Noll, G. (2003). Risky games? A theoretical approach to burden-sharing in the asylum field. Journal of Refugee Studies, 16, 236-252. Oberman, K. (2016). Immigration as a human right. In S. Fine, \& L.Ypi (Eds.), Migration in political theory, (pp. 32-56). Oxford: Oxford University Press.

Owen, D. (2016). In loco civitatis: On the normative basis of the institution of refugeehood and responsibility for refugees. In S. Fine, \& L. Ypi (Eds.), Migration in political theory, (pp. 269-289). Oxford: Oxford University Press.

Rapoport, H., \& Moraga, J. F.-H. (2014). Tradable refugee-admission quotas: A policy proposal to reform the EU asylum policy. (RSCAS Working Paper 2014/101). Florence: EUI.

Rodrik, D. (2011). The globalization paradox: Democracy and the future of the world economy. New York: W. W. Norton \& Co. Schotel, B. (2011). On the right of exclusion: Law, ethics and immigration policy. London: Routledge.

Shachar, A. (2009). The birthright lottery. Citizenship and global inequality. Cambridge: Harvard University Press.

Walzer, M. (1983). Spheres of justice. A defense of pluralism and equality. New York: Basic Books.

\section{Submit your manuscript to a SpringerOpen ${ }^{\circ}$ journal and benefit from:}

- Convenient online submission

- Rigorous peer review

- Open access: articles freely available online

- High visibility within the field

- Retaining the copyright to your article

Submit your next manuscript at $\boldsymbol{\sim}$ springeropen.com 